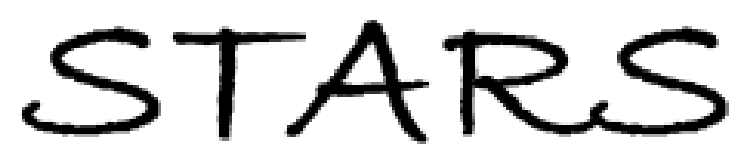

University of Central Florida

STARS

Faculty Scholarship and Creative Works

$10-1-2020$

\title{
Situational and Personal Factors Influencing Hospitality Employee Engagement in Value Co-creation
}

Prakash K. Chathoth

Robert J. Harrington

Eric S. W. Chan

Fevzi Okumus

University of Central Florida, Fevzi.Okumus@ucf.edu

Zibin Song

Part of the Hospitality Administration and Management Commons, and the Tourism and Travel Commons

Find similar works at: https://stars.library.ucf.edu/ucfscholar

University of Central Florida Libraries http://library.ucf.edu

This Paper is brought to you for free and open access by STARS. It has been accepted for inclusion in Faculty Scholarship and Creative Works by an authorized administrator of STARS. For more information, please contact STARS@ucf.edu.

\section{Original Citation}

Chathoth, P. K., Harrington, R. J., Chan, E. S. W., Okumus, F., \& Song, Z. (2020). Situational and personal factors influencing hospitality employee engagement in value co-creation. International Journal of Hospitality Management, 91, N.PAG. https://doi.org/10.1016/j.ijhm.2020.102687

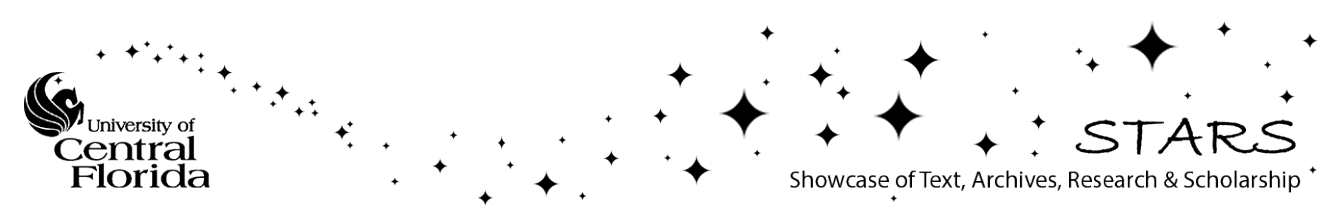




\title{
Situational and Personal Factors Influencing Hospitality Employee Engagement in Value Co-creation
}

\author{
Prakash K. Chathoth, Ph.D. \\ Professor \\ Department of Marketing and Information Systems \\ School of Business Administration \\ American University of Sharjah, PO Box 2666, Sharjah, UAE \\ Robert J. Harrington, Ph.D. \\ Professor \\ School of Hospitality Business Management \\ Carson College of Business \\ Washington State University Tri-Cities \\ Richland, Washington, USA \\ Eric S.W. Chan, Ph.D. \\ Associate Professor \\ School of Hotel and Tourism Management \\ The Hong Kong Polytechnic University \\ 17 Science Museum Road, TST East, Kowloon, Hong Kong \\ Fevzi Okumus, Ph.D. \\ CFHLA Preeminent Chair Professor \\ Rosen College of Hospitality Management \\ University of Central Florida \\ Orlando, Florida, USA \\ Zibin Song, PhD \\ Professor \\ Tourism School of Hainan University \\ Haikou, Hainan, PR China
}

Acknowledgement: This research project (1-ZVGR) was funded by the Hong Kong Polytechnic University. 


\title{
Situational and Personal Factors Influencing Hospitality Employee Engagement in Value Co-creation
}

\begin{abstract}
This study explores the situational and personal factors affecting hospitality employees' engagement in the co-creation of value. The concept of value co-creation emerged from the general co-creation literature, and little research has assessed how situational and personal factors enhance our understanding of value creation. To explore these underlying factors, a qualitative study involving in-depth and focus group interviews was conducted at three luxury hotels in Hong Kong and Macao. The research findings indicate five situational factors and five personal factors impact cocreated value for hotel guests in the luxury sector. Insights are provided into the potential use of these factors to better manage employee engagement and the customer experience to facilitate value co-creation. The implications of the study and directions for future research are discussed.
\end{abstract}

Keywords: Co-creation, Value, Employee engagement, Hospitality, Situational factors, Personal factors

\section{Introduction}

Value co-creation through the lens of the service-dominant (S-D) logic (e.g., Buhalis and Foerste, 2015; Vargo and Lusch, 2004) has produced considerable work that focuses on the responsibilities customers and service providers share to create value in service transactions (Ramaswamy and Ozcan, 2018; Prahalad and Ramaswamy, 2004a, 2004b). Given the processoriented nature of value co-creation, several studies have called for further research to provide empirically grounded examples of co-creation processes at different levels of analysis (customer, employee and organisational) (Chathoth et al., 2016; Hansen, 2017; Yi and Gong, 2013). Discussions of value co-creation have distinguished between the concepts of value-inexchange, value-in-use, value-in-context and value-in-experience (Hansen, 2017). These are 
shaped by the actors involved in the transactions and the interactions as well the level of engagement between them.

The diversity of these value constructs has facilitated the development of emerging literature in the context of hospitality and tourism (Chathoth et al., 2013, 2016; Harkison, 2018; Harrington, et al., 2019; Ma et al., 2017; Prebensen and Xie, 2017). Hospitality research is based on the assumption that hospitality service is situational and more closely aligned with the logics of value-in-context and value-in-experience than those of value-in-exchange or value-in-use (e.g., Harrington et al., 2019; Lashley, 2017). Therefore, it is imperative to study the factors that lead to the creation of the value-in-context and value-in-experience, underlying the reciprocal interaction leading to customer and employee engagement (González-Mansilla, et al., 2019).

It is essential to highlight that employee engagement in the co-creation of value is important to consider as the reciprocal interaction between the customer and the firm is influenced by the level at which the employees engage in the transaction. The engagement of employees in this case is considered from the perspective of the creation of value for the customers and the firm. The factors that influence the level at which employees engage need to be studied in order to further our understanding of what these factors are that have an influence on the co-creation of value. Accordingly, situational factors are important antecedents in value-creating processes. They are defined as factors involving the service agent and the customer that arise from the specific situation just preceding or accompanying the value co-creation process. For instance, situational factors include whether sufficient manpower is available to operationalise co-created customer value. Likewise, personal factors are defined as the inherent skills, traits and characteristics of the service agent that are intrinsic to the individual, which may influence employees' willingness and ability to engage in the process of value co-creation (e.g., Tsaur, et al., 2019). Therefore, it is imperative that factors that foster 
customer-employee engagement be investigated along with the effect on co-creation of value. This will enable firms to manage the process of co-creation and resources across the entire experience more effectively (Voorhees, et al., 2017).

The majority of studies on co-creation behaviour have focused on the firm or taken a customer perspective on value creation (Hansen, 2017; Yi and Gong, 2013). Few general business or hospitality studies have articulated the role of employee engagement related behaviour in value co-creation. Those that have appear to have focused on work engagement as a motivation construct from a human resources management perspective (rather than investigating the role among the firm environment, employment engagement, situational and personal factors as a locus for value co-creation) (Dai, et al., 2019; Gordon, 2020; Paek, et al., 2015; Tsaur, et al., 2019). This is a major gap in the existing literature related to co-creation. Because co-creation is based on the reciprocal interaction between customers and employees, the need to delve into the employees' side of the transaction is required to further understand how it is effectuated in service experiences. While recent research has articulated the connection between service adaptation to customer specific needs leading to increased value (González-Mansilla, et al., 2019), no significant research to date has been published that provides a rich description of the influence of situational and personal factors on this process (Chathoth et al., 2016). Questions remain as to how situational and personal factors affect potential perceptions of co-created value and how these dynamic interactions are facilitated via employee engagement. The literature detailing the personal factors is from the perspective of how employee characteristics, skills and traits influence transactions in general (Bakker and Schaufeli, 2008) and in hospitality (Dai, et al., 2019; Gordon, 2020). Thus, it is important to reiterate and explore the role of employees in the co-creation process and that situational and personal factors affect the co-creation process. 
Given the importance of the topic, especially for high-end services, the purpose of this study is to address the above research gap by examining the effects of situational and personal factors on value co-creation from the employee's perspective in full service hotels. Co-creation of value is integral to the transactions in luxury and upscale hotels; therefore, this setting is conducive for the study related to the abovementioned objectives. The nature of the transaction in upscale and luxury hotels is such that there is a superior level of employee engagement in the co-creation of value as compared to other types of hotels (such as mid-priced and economy hotels). This is more so because of the service component in the goods-services bundle is at a higher level. As a result, the intangibility inherent in value co-creation is at the higher end of the spectrum requiring the employee to engage at a higher level to create value for customers. Therefore, studying co-creation in such a setting would be more useful to meet the objectives of this study. The study explores the specifics of employee engagement factors with the goal of ascertaining key situational and personal influencers of co-creative processes in luxury/upscale hotels. Using an exploratory design, the study posits that insights into employees' role and behaviour in co-creating customer experiences are critical for rich understanding of this reciprocal and value co-creation process.

The following sections outline 1) the concept of co-creation, definitional issues and the service dominant (S-D) logic; 2) broader employee engagement factors; 3) the exploratory methodology used; 4) and the study results, which unearth key situational and personal characteristics, the specific impacts of these factors and how they can be addressed in the hospitality industry.

\section{Value Co-creation}

The joint creation of value is at the heart of the co-creation process involving a firm and its customers (Kristensson, et al., 2008; Prahalad and Ramaswamy, 2004a). The processes and systems of joint value creation include engagement platforms (Chathoth et al., 2016) that 
lead to the co-construction of customer experiences (Grönroos, 2008) through interactions with service agents (Binkhorst and Den Dekker, 2009; Assiouras et al., 2019), and "learning" from customers (Yachin, 2018). The “co-creative strategy”, as per Ramaswamy and Guillart (2010), comprises a continuous focus on customer experiences and progressive service improvements. In such a dynamic system, collaboration between various functions within the firm is a critical component of the processes involved. Ramaswamy and Guillart (2010) provide a detailed account of what constitutes co-creation while specifically identifying the principles of cocreation to essentially encompass the following: 1) value needs to be created for all stakeholders involved, without which they would not fully participate or be involved in service exchanges; 2) experiences are at the crux of value co-creation functions/activities involving all of the firm's stakeholders; 3) interaction between stakeholders forms the basis of value creation; and 4) engagement platforms should be created to get the stakeholders to interact with each other in order to share experiences, knowledge, and other such resources. The essence of co-creation lies in the linkage between the consumer, the experience and value creation (Prahalad and Ramaswamy, 2004a).

This linkage between the customer, the experience and value overlaps implicitly with the concept in the marketing literature of the 'customer journey'. While being focused on the multiple steps by consumers leading to the ultimate purchase outcome (Lemon and Verhoef, 2016: 82), similar to co-creation, the customer journey is perceived as a pre, during and post experience concept and is impacted by the other actors involved in this experience or journey. Therefore, the construct of the customer journey fits closely with articulating how value is cocreated (before, during and after the experience) and how situational and personal factors are likely to impact value creation during the service prevision, purchase outcomes and other behaviours (i.e. loyalty, e-WOM, etc.). 
While value is subjective, it has often been described as a vital aspect of success in the modern competitive environment (González-Mansilla, et al., 2019; Yachin, 2018). The essence of co-creation lies in the link between the consumer and the experience (Pine \& Gilmore, 1998; Shaw, et al., 2011), and the creation of value. Experiential value is generated when co-creators (customers, employees and other stakeholders) interact to create appropriate customer experiences (Grönroos, 2008, 2012; Assiouras et al., 2019), including feelings and emotions (Smith and Colgate, 2007). For experiential value to be realised, recent findings indicated hotels should create a suitable environment that leads to reciprocal interactions and value cocreation (González-Mansilla, et al., 2019). Due to the importance of the joint creation of the product-service bundle through employee-customer interfaces, co-involvement and engagement are critical to the creation of value (Prahalad and Ramaswamy, 2004a, 2004b).

Customer-employee interfaces lead to relationship building and stronger association between the actors in a service transaction (Payne et al., 2008), deeper shared engagement that has an effect on value co-creation (Prahalad and Ramaswamy, 2004a), and, ultimately, increased brand equity, customer loyalty and customer satisfaction (González-Mansilla, et al., 2019; Tsaur, et al., 2019). Co-created value is closely tied to the experiential value derived in part from the interaction between the primary actors (customers and employees). For both groups of actors to create value through co-creative modalities, it is necessary to emphasize on behaviours that address the situational and personal factors that influence value co-creation (Chathoth et al., 2017). Accordingly, this study focuses on the situational and personal factors that influence employee engagement in value co-creation in the hospitality context.

Co-creation oriented service environments are influenced by customers' motivation and degree of participation in value creation (Ramaswamy and Ozcan, 2018). Value co-creation entails two-way communication between customers and employees to foster a flow of information (i.e., customer specific information capturing preferences) (Dong et al., 2008; 
Buonincontri et al., 2017), conversation and interactivity. This is intended to initiate dialogue, provide access to resources of value creation while minimizing customer and firm risk while at the same time increasing transparency in the co-creation of value (Prahalad and Ramaswamy, 2004b). González-Mansilla, et al. (2019) noted that for co-created value to take place in the hotel context the customer-firm actor relationship should reduce risk, create dialogue, transparency and access. Thus, the flow and use of information in the exchange process are employee and customer dependent, and therefore exposed to situational and personal factors, which influence utilitarian and experiential value creation.

\section{Employee Engagement}

Employee engagement is a 'set of motivating resources such as support and recognition from colleagues and supervisors, performance feedback, opportunities for learning and development, and opportunities for skill use' (Bakker and Schaufeli, 2008; p. 151). This also encompasses the incumbent's levels of motivation and commitment, which can lead to performance that exceeds employer expectations. In this research, employee engagement encompasses the employee related resources that support engagement and the employee's inherent motivation, commitment and involvement in terms of fostering value creation in service transactions. Recent research in hospitality has used the term work engagement as a motivational construct and personality factors such as psychological capital (Tsaur, et al., 2019), organisational vs. supervisor support (Gordon, 2020), and the impact of an abusive supervisor (Dai, et al., 2019).

The broader literature has further identified various internal and external factors that influence employee engagement (see Chang, 2016; Mullins, 2007). These factors are situational, organisational and personal, arising mainly from (a) the service transaction itself, which is situation specific; (b) organisational factors; and (c) personal factors, i.e., related to 
the employee (Mullins, 2007). However, the literature has not explored how situational and personal factors influence service provision, particularly in relation to co-creative processes. Although not directly related to co-creation, situational, personal and organisational factors specific to the hospitality industry have been identified in studies such as Mullins (2007) and Chang (2016). Chang (2016) identified employee behaviours that contributed to service delivery, emphasising the moderating effects of service climate and employee engagement at the firm level, showing how engagement related situational and organisational factors (servicescape and climate) affected customer consumption experiences in a service firm. Chang (2016) also highlighted the need to delve into not just individual (personal) but also environmental (or situational factors), providing a rationale for investigating these factors in service transactions from a co-creation perspective.

Moreover, the literature suggests that organisational resources and work engagement are related to employee performance and customer loyalty (Salanova et al., 2005; Tsaur, et. al., 2019) as well as consumer perceptions of whether or not the firm favours the process of value co-creation (González-Mansilla, et al., 2019). A positive organisational climate and service climate increase customer satisfaction in hospitality firms (Johnston et al., 2013). Employee engagement is an integral component of such an organisational/service climate. As such, the positive relationship between employees' own perceptions of the service climate and their impact on service performance was supported by Chathoth et al. (2007) from a hotel industry perspective. However, it is not clear which types of situational factors (including subfactors) influence employee engagement that co-create value. Accordingly, the overarching research questions are as follows. What situational factors or subfactors influence the engagement of employees in co-creative service transactions? What employee related personal factors influence the engagement of employees in co-created transactions? If situational and personal factors are likely to impact the viability of co-created value propositions, the identification of 
these factors is critical to facilitate consumer value creation. These questions provide a foundation for the methodology used in this study, as detailed in the ensuing section.

\section{Methodology}

Qualitative data were collected to tease out the key situational and personal factors related to employees' role in value co-creation. The use of qualitative data was warranted given the exploratory nature of the research. It should be noted that the situational and personal factors impacting employee engagement in co-creation has not been explored within the hospitality and/or generic literature from an employee perspective (Yi and Gong, 2013). To accomplish the research objectives, focus group discussions, which are effective in generating qualitative data (Krueger and Casey, 2000), were conducted with a convenience sample of employees from three luxury Hong Kong/Macao hotels. To maintain consistency and in order to avoid interviewer bias, the first author assumed the role of the main interviewer /moderator for all interviews. The second author monitored, tracked and recorded them. Both authors have previous experience in conducting qualitative research. The hotel industry is an appropriate context for exploring employee engagement because the experiential components of the product-service bundle in high touch services, specifically in the co-creation of services (e.g., Chathoth et al., 2014), are determined by dialogue, access, risk and transparency (Prahalad and Ramaswamy, 2004a). The three hotels chosen for data collection were well-established global brands known for their sophisticated service delivery.

Forty-two management/supervisory level employees from the three hotels (Hotels A, B and C) participated in the study over a three-day period. Since the study included factors influencing employee engagement in the co-creation process, management and supervisory staff were considered as more relevant to this study than frontline employees. Since the nature of the job of management and supervisory staff includes dealing with situational and personal 
factors influencing employee engagement, they were considered for this study. In particular, since this study relates to the identification of situational and personal factors that influence employee engagement in the co-creation of value, management and supervisory staff that are instrumental in setting the standards of service were considered as more appropriate for this study. Two sets of focus group interviews were conducted (in English) with key managers/supervisors in each hotel. Focus groups were used for the study as this allowed the participants to share information related to their level of engagement in the co-creation process. They are effective in the generation of qualitative data that is rich in content related to attitudes, perceptions and opinions of participants (Krueger and Casey, 2000) on a given topic. Eleven of them were from Hotel A, 13 from Hotel B and 18 from Hotel C. There were at least six employees in each focus group, except one with five (see Raibee, 2004). By and large, the managers held customer contact positions related to room division and food and beverage service. The majority of the incumbents had a tenure of 9-11 years, reflecting considerable exposure and experience, and a Bachelor's degree in hospitality management conforming to industry-wide standards in Hong Kong/Macao. The focus groups were comprised of more female employees (55\%) than male employees. The age groups these participants represented are as follows: $9.5 \%$ in the $18-25$ category, $54.7 \%$ in the $26-34$ category, $28.6 \%$ in the $35-45$ category and $7.1 \%$ in the $46-55$ category. Conducting two focus groups consecutively (in this two-stage process, see White et al., 2009) ensured that content was not shared between the two sets of participants. The two-stage process was used to ensure that the exploratory nature of the research process led to conclusive findings (and data saturation) through interactions with two separate sets of executives/managers/supervisors of each hotel.

A semi-structured format was used to ensure participant response, using an interview guide, which was sent to gatekeepers at all three hotels at the outset. The interview guide included three sections. The objective closed-ended questions were filled out by the 
participants at the beginning which helped to reduce response and respondent bias while serving as a screen for inclusion of the three hotels. These questions focussed on the hotel's level of service flexibility (Q1A), the level of customers' involvement in creating their own experiences (Q1B), employees' involvement in creating guest experiences (Q1C) and the level of information processing during the provision of services (Q1D) (see Table 1). Overall, respondents rated all four of the above categories as above 'average' with more than half of the respondents rating them as 'high' to 'very high' - no responses were in the 'low' or 'very low' categories. The second section comprised of open-ended questions (see Appendix A) serving as a guide for the interviews themselves; whereas, the third section included questions on respondents' background. The broader literature provided a basis in questionnaire development and laying the foundations of the study.

Insert Table 1 about here

\section{Data Analysis}

The transcripts, which were obtained through transcription of the recorded interviews verbatim, were analysed for common themes, patterns, threads and sequences that gave credence to the broader conceptual underpinnings on employee engagement in each hotel service context. As not much literature exists on employee engagement in service systems that use co-creative modalities, the broader literature became the basis to tease out broader concepts on employee engagement, in general, and situational, in particular. This provided a basis for using deductive research to the extent possible in this study; exploration through probing led to generation of rich data that were context specific and inductively based (Miles and Huberman, 1994; Yin, 2009). The literature review provided a basis to develop a coding 
scheme to categorize the interviews which then led to the generation of themes and mapping of concepts. The coding scheme was reviewed and agreed to by all authors. Associations between concepts and the underlying explanations led to a systematic development of specific variables and linkages as they relate to the topic. These findings specific to situational and personal factors are detailed in the next section.

\section{Findings}

The data collected from the three hotels revealed key factors that influenced employee engagement in co-creative services. These factors were further analysed and categorized into situational and personal (detailed below in that order), as detailed in Table 2.

Insert Table 2 about here

\section{Situational Factors}

The underlying logic used to categorise the factors was provided by the broader literature; situational factors were understood to be based on localised transactions specific to guest related requirements, which influence the organisation and its employees and are beyond the direct control of the firm. The quotations below have been edited to correct grammatical errors and meet textual requirements without changing their inherent meaning.

Understanding customer needs: Engagement is fostered when employees empathise and interact with guests to uncover customer needs, which vary from situation to situation. To co-create customer value, employees must involve themselves as much as possible in the situation and find out what customers really need. Individual level interactions can be used by employees to evaluate guest needs and co-create experiences. A Hotel A participant underscored the importance of understanding customer needs: 'But you need to touch their 
[guests'] hearts. How can you do this? You have to make sure you know their needs. It is actually a culture'.

Observation was identified as an effective method of identifying guests' needs. Guest preferences were monitored and services adjusted based on employee observations and information processing. One-on-one interactions in which the employees asked guests about their needs with follow-up on specific needs were also effective. This was emphasised by a Hotel C executive: 'we play a big role as a service provider in creating memorable experiences for our guests. If one of our ambassadors [employees] sees that a guest's shoes are very wet because of heavy rain, she will volunteer to help the guest to dry and polish his or her shoes'. Meeting customer-specific needs in a hotel environment can be challenging if the system is not effectively managed. For instance, some participants reported that an excessive focus on guests' idiosyncratic needs can create a barrier to good service.

Customer-employee interaction: Participants reported that employees' interactions and communication with customers (seen as a precursor to co-creation) through informal conversations helped them to connect with customers at a deeper level, fostering the cocreation of experiences. The greater the employees' interaction with guests - the greater their likelihood of engagement. Guests' familiarity with the service environment, which was situationally driven, was also identified as affecting their (the guests') role and involvement in co-creation. This was supported by a Hotel A participant: 'Sometimes I think [co-creation] comes through conversation. With first-time guests, this is very difficult, unless we are able to interact with them maybe during check-out or check-in, during their stay or maybe in the restaurant, when we can talk to them to see what they would like,... and then we can capture the information ..., for example, they might need a slightly harder pillow, right? Maybe a guest always wants well done beef, for instance’. 
Guest involvement increased between the pre-arrival and arrival phases in a typical hotel transaction. This further indicated that the physical interaction between guests and employees is conducive to a higher level of co-creation. However, the greater use of technological interfaces at the cost of physical personal interaction was seen as a barrier to high-quality interactions. The participants felt that customer-employee interactions were better managed at the individual than the system level. Positive customer experiences resulted when hotel staff were able to handle personal (idiosyncratic) customer requests. This set up a platform for exchange and relationship building.

A Hotel B executive highlighted the importance of 'touching our guests' hearts [by offering them] something unique that they cannot experience somewhere else, or not to the extent of personalisation that we deliver. One example... is when we invite them to eat in our staff restaurant. They find this so unique and memorable. Management even joins this kind of gathering [platform for exchange and interaction]'. In essence, such interactive platforms created an enhanced sense of personal connection and engagement, facilitating the building of customer relationships, which was seen as an important aspect of customer-employee interactions.

Customer status. The status of the guest impacted the degree of service orientation, including flexibility and engagement. The participants reported that all else being equal, guests' status (i.e., VVIP, VIP or non-VIP/regular guest) determined the potential to co-create experiences for them. As such, employees' guest orientation - i.e. their involvement and engagement in service transactions - was influenced by guests' status, which was defined primarily by each hotel's SOPs (standard operating procedures). Guests' status was to some extent also defined by their purpose of travel, i.e., business or leisure.

For instance, a Hotel C executive reported that 'for VIPs, we can achieve more than 90\%' of guests' specific housekeeping needs. An executive from Hotel B stated that 'I believe 
that it [engagement with and of guests] is average, because most of our clients are business travellers. Business travellers... basically [need] a quick check-in, a quick check-out, a comfortable room to stay in and prompt services'. Accordingly, the potential for employee engagement is at the lower end of the spectrum for these guests. 'If we look at leisure guests' involvement, I'll put it this way, it takes time for the guest, as well as the staff, to really build a rapport before we really get some involvement and enrichment'. Guests' cultural background and language skills were also seen to affect their ability to co-create services.

Customer engagement. A guest's level of engagement has an important influence on the provision of co-creative services, hence employee engagement. Guests learn about the potential to co-create when they interact with hotel employees on an individual level. Individual service orientation is localised at the transaction level and depends on the orientation of the customer. If $\mathrm{a}(\mathrm{n})$ hotel/employee is able to foster in guests an individualistic orientation and a high level of involvement and engagement in information sharing and service delivery, co-creation will emerge.

In particular, employees described the co-creation of experiences as a product of the amount of information the guest shared with the hotel at the time of service provision. For cocreation to occur, it was imperative for the guest to engage in the process as much or even more than the employees. According to a Hotel A executive, 'The initiation has to come from the guest usually'. Guests' idiosyncratic needs are known only to the guests themselves. 'That initial spark, the request, comes from the guest, and then we handle special requests accordingly. If something is guest experience related, our guest experience team will handle it. They will reach out directly and sort of either provide options or get additional information, and they can tailor the experience based on feedback from the guest'. Therefore, customer engagement is vital to ensure that employees engage in the co-creation of services and experiences. However, customer engagement is also influenced by the profile/background of 
the guest in question. According to the participants, not all guests wanted 'special treatment' to address their idiosyncratic needs; many followed the generic brand standards established by the hotel.

Customer attitude and behaviour. A customer's orientation towards a transaction was seen to influence employee engagement either positively or negatively, depending on the customer. Some participants highlighted that guests' behavioural orientations and attitudes affected service situations that required co-involvement from employees and guests. Positive customer attitudes and behaviour were required for employees to provide superior services, especially when such services went beyond what was stipulated in their firms' SOPs. This was also dependent on the employees' behaviour, which was both influenced by the customer's disposition towards the service being provided and a function of the employees' attitudinal orientation (detailed under personal factors). The customer's background (including culture) and ability to communicate influenced employees' involvement/engagement in the service cocreation process. In this regard, a Hotel A participant stated 'one barrier is guest behaviour, because a lot of our guests absolutely take advantage. You give them one thing, they take your whole arm. It is entirely up to us how we communicate the limitations. If we open up more opportunities for them, they will absolutely take advantage times 10'. This kind of behaviour negatively influenced employees' involvement in transactions.

\section{Personal Factors}

Employee propensity to process information: The propensity to process information is an intrinsic personal factor. Some employees are more receptive to information processing than others, due to characteristics such as behaviour, attitude, motivation and skills. Our data revealed that the personal skills of employees, as co-creators of services, were essential to their processing of information to personalise services and create positive experiences. Moreover, employees' ability to manage specific customer requirements was a function of their skills and 
ability. Employees' skills enabled them to determine what information was relevant and useful to value co-creation, with information seeking identified as important by the participants. The ability to seek information to solve customer problems and meet specific needs was seen as an important personal level attribute. Specifically, the capacity to process individual level information was considered vital to the process of identifying idiosyncratic, situation-specific customer needs, leading to experience co-creation.

Employee level of empathy: Empathy was seen as a prerequisite for building personal connections and co-creating services in a high touch service hotel setting. For co-creation to occur, employees needed to step into the shoes of their guests and anticipate their needs. A participant from Hotel A stated that 'we have a great focus on empathy. If a guest informs us that he has lost his suitcase, it's not like the conversation ends there; we are sort of encouraged to ask a second question to provide a solution instead of waiting for the guest to ask us. We empathise with them, [find out] what their situation is, then proactively offer solutions'.

Another Hotel A participant elaborated further: 'Being empathetic is very important, because every single guest has different needs. If you are not able to identify and meet their needs, [if] you just follow the [hotel] standards, you will not be able to make them happy. From the first day they [employees] join us... we give them the same message, make sure they are empathetic'. This was confirmed by a Hotel B participant: 'When they [guests] arrive, we personally meet and greet them. Of course, this depends on the guests' mood, purpose of travel, etc.; if they are not that talkative, then we will not engage them too much. But if guests are very willing [to be engaged], ... we can anticipate their needs and do something special'.

Employee skills and work experience: According to the participants, the more experience an employee had, the better able s/he was to co-create services. Familiarity with guests was directly attributed to employee experience and considered an important aspect of personalising experiences. A Hotel B executive indicated 'of course, it depends on the 
experience of that employee and how creative and proactive he or she can be going above and beyond to provide service that "wow" the guest'.

Moreover, employees were required to think 'outside the box' to find service solutions for customers. This was directly related to their skills in and experience of managing customer experiences. Generally, the participants stated that organisational tenure and employee experience positively impacted employees' ability to deliver superior services. However, according to some participants, employee tenure above a certain level could have a negative impact on motivation, as stated by a Hotel B executive: 'we also have some colleagues who have been here forever. So they are less motivated'.

Employee behaviour, attitude and motivation: Employees' positive attitudes towards solving guests' problems and creating positive experiences for them by meeting their needs are integral to value co-creation. Employees' passion was identified as an important aspect of the service climate in this study. A Hotel C employee stated that 'it's attitude, it's the mindset. ... you need the right people, right? In a hotel with 400 or 500 employees, does everyone have the right attitude? Difficult... If you work in this industry, you know it, all that drives us is passion'.

The participants reported that employees' level of motivation influenced their involvement and engagement in services that required the co-involvement of customers. Employees needed to be motivated to the extent that guest problems were seen as opportunities and not problems. A giving and caring employee attitude was critical to ensure a superior service orientation. Intrinsic motivation was essential for a superior service orientation. Guest satisfaction was itself a motivator in terms of engaging employees at a higher level. A Hotel C participant pointed out that 'when you see the satisfaction on a guest's face,... then you feel happy with them... there are other ways to motivate [a service employee]'. Another Hotel C executive agreed that creating 'wow' moments actually motivates employees: 'if a guest has a 
preference for a particular cheese or cola, we can arrange for it to be there before he or she arrives; surprise him/her. Create a "wow" moment and I am sure he/she will be very satisfied'.

Whereas a problem-solving attitude was imperative to enable employees to deliver superior services, employee recognition helped to influence and reinforce positive behaviour. A Hotel B executive stated 'good comments from guests [are shared] with ... colleagues to [inform] that the staff involved have done a very good job. Everyone puts in more effort... to be one of the staff praised by guests. That's one of the motivations. We also have a human resources scheme..... when they achieve a certain number [of positive comments from guests], they [the staff] receive free lunch with the management'. Guest feedback was seen as a means to motivate employees, which then influenced their level of engagement in service co-creation. The end result, i.e., repeat visits by customers, was reported to be an equally important source of motivation for employees in a high touch service environment.

Employee personality traits: Employees' personality traits was also seen to influence employees' involvement and engagement in services co-creation. These traits determined whether and how the employees went beyond what was stated in their hotels' SOPs. The participants stated that the hotels' SOPs did not usually include co-creation related service standards. Therefore, employees needed to go beyond the stated SOPs to deliver experience co-creation, which brought the influence of their personality traits into play; these traits also influenced their use of co-creative modalities of value creation.

Employees' demeanour, proactiveness and introspection were identified as important traits in a high touch environment. Anticipation of customer needs (i.e., proactiveness) was a prerequisite for managing customer experiences effectively. Introspection was also seen as a key trait, requiring employees to reflect on whether services met customers' idiosyncratic needs and whether service outcomes met brand standards. They needed to seek new information to update brand standards to ensure that their hotels were prepared to meet guests' requirements. 
Employees also needed to assume ownership of service situations (responsibility for delivering the services). Employees' emotional engagement was seen by some as a requirement for the delivery of superior services. A Hotel $\mathrm{C}$ executive stated 'sometimes... the guest may design the service without even asking. However, our employees take the initiative and actually make [the service] happen even before guests voice their needs'.

Moreover, the employees needed to hone their ability to manage work related stress and services on a day-to-day basis. A good work-life balance was needed for effective management in the hotel service environment. This was pointed out by a participant from Hotel B: 'work-life balance - that's one of the motivations to improve [employee] morale for us'.

\section{Discussion and Conclusions}

This research aimed to identify the key situational and personal factors that facilitate hotel employee engagement and value co-creation. The findings indicate that intensive employee engagement driven by situational and personal factors play an important role in managing co-created hospitality services. One of the challenges of this project was identifying a clear distinction between situation and personal factors impacting value co-creation. In the end, the authors realised that these are not mutually exclusive in all cases and where separated in the findings section based on predominately if situational or personal in nature. The current study provides rich descriptions of how customer-employee interactions and value co-creation are driven by situational or personal factors. Both factors are probable drivers; thus, an assumption of this study is the understanding that some overlap of situational and personal factors exists. This overlap is represented in the overlapping ovals in Figure 1 outlining situational and personal factors. The basis for theoretical and practical elements shown in Figure 1 are outlined in the implications sections that follow.

Insert Figure 1 about here 


\section{Theoretical implications}

The situational and personal factors identified in this study offer a framework for smoothing the customer journey and increasing the likelihood of cultivating co-created value and other positive outcomes (Figure 1). This framework draws on earlier studies on managing and designing the customer experience (Chase and Dasu, 2014), concepts associated with the customer journey (Lemon and Verhoef, 2016), and other studies specific to hospitality and tourism co-creation (Hwang and Seo, 2016; Yachin, 2018). Customer experience management (CEM) has been described as a key management objective. Multiple definitions of CEM exist but from the firm point-of-view the concept relates to "the firm essentially designing or crafting an experience for the customer to receive (Lemon and Verhoef, 2016: 70)." This perspective is tied to the service dominant logic concept with co-creation resulting from a culmination of the consumer's interaction with other actors in the ecosystem. A boundary condition of this study and model is a focus on the firm perspective and interest in situational and personal factors that impact employee engagement (ecosystem actors of interest) in a luxury/upscale hotel context.

While this involves a level of design at the organisational level, the customer journey throughout the experience process employs a complex number of touchpoints. Not surprisingly (and shown in this model), the ability to address customer journey complexity as well as situational and personal factors that are embedded in the process demand employee engagement to address or mediate these complexities. While traditional models suggesting a path-to-purchase and touchpoints have seen increased interest due to increases in virtual components of service experiences (Lemon and Verhoef, 2016), our insertion of organizational, situational and personal factors within CEM and the customer journey reflects 1) a firm-level need to address internal design to provide flexibility for situational and personal issues, as well as the assumption that 2) the general weakness of modelling customer journey 
behaviour and assessing the designed touchpoint process is that this process is not always sequential; internal and external factors (situational and personal) impact the management of the experience; and critical touchpoints along the journey become potential moments-of-truth demanding employee engagement to influence key customer outcomes such as value cocreation.

The above assertions are supported by the current study and a synthesis of earlier studies with customer and employee characteristics serving as antecedents to experience perceptions and, ultimately value perception outcomes (emotional, behavioural and brandrelated) (Hwang and Seo, 2016). Additionally, situational factors, personal factors, employee engagement and value co-creation appear to be implicit in the findings of recent study in tourism. Yachin (2018) suggested that successful customer journey experiences in tourism require learning from the customer, intensive encounters between firm actors and customers, and that value derived from these experiences are subjective yet vital for both value realization and recollection. While Yachin (2018) argued that the character of firm actor-customer encounters is the locus of value creation, our findings indicate engagement to adapt experiences to a variety of situational and personal factors is required to serve as a locus for value cocreation.

Figure 1 is based on our qualitative study and enhances the current literature on value co-creation and employee engagement. Customer experience management involves internal aspects of the service design that are likely to impact perceptions of quality and value. The notion of value co-creation involves a reciprocal interaction between the customer and hotel for it to occur (González-Mansilla, et al., 2019). While Lusch and Vargo (2006) argue that the customer is always a co-creator of value, González-Mansilla, et al. (2019) suggest that value co-creation is only possible when the hotel creates a suitable environment for interactions to occur. Thus, although these elements emerge from organisational factors and decisions, they 
are impacted by situational and personal factors that may positively or negatively affect employee engagement and value co-creation. We argue that these situational and personal factors driven by employee engagement become levers for what has been more vaguely termed "value-creating processes" (González-Mansilla, et al., 2019: 52).

While organisational factors are not fully analysed in the current qualitative study, it stands to reason that they will impact the ability and willingness of employees to engage with customers to address situational and personal factors that become evident. For example, organisational factors or decisions would likely impact situational factors such as understanding customer needs, the customer-employee interaction, and customer status identification with platforms set up to facilitate communication, loyalty program information and so on. The same could be argued for personal factors based on organisational decisions such as reward systems, training and selection processes. With that said, many of the situational and personal factors identified are impacted by employee traits, professional culture and personality.

A number of recent studies have looked at work engagement by employees as a key factor that impacted customer loyalty and satisfaction (Dai, et al., 2019; Gordon, 2020; Tsaur, et al., 2019); the focus was looking at work engagement as a motivational construct and is beyond the scope of the current study. The current study adds to the employee engagement implications by articulating firm-actor engagement characteristics that need to be embedded in the reciprocal interaction to facilitate value co-creation. This notion of reciprocal interaction was supported in the current study by the use of situational variables (i.e., the type of interaction, guest involvement, informal conversations, and relationship building) and personal variables (i.e, information seeking behaviour, affinity for information processing, motivation, and willingness to engage). 
In summary, theoretical implications of this current study span the connection between predominately customer-driven research streams (modelling the customer experience or journey) and predominately employee-driven research streams (assessing the motivational and psychological factors that impact work engagement). The integration of these concepts supports a firm's need to assess appropriate customer-firm actor reciprocal interactions as part of the overarching strategy and developing underling tactics to achieve it. The current framework points to the internal need to facilitate value co-creation through engagement activities that provide clues to customer needs, behaviours and information processing. The activities articulated in this study and framework contribute to more fully recognising the evolving customer-employee interactions, employee engagement needs, and expand the lens for managing resources across the entire experience for both customers and employees.

\section{Practical implications}

A variety of elements in the holistic service experience were uncovered in this study for both situational and personal factors. From a practical standpoint, the ability to utilize this greater understanding of situational and personal factors and variables that impact value cocreation requires planning and processes from top management, mid-management and from frontline staff. At the organisational level, top management strategic planning should be completed that facilitates systems, platforms and a culture to drive the situational/personal factors and variables identified in this study. Mid-management should reinforce processes and systems that 1) maintain a culture and climate that rewards and recognizes employee engagement, 2) promote a selection process that identifies the characteristics of staff in this

study, and 3) create training programs to promote the behaviours identified in this study. Frontline staff have a role as well; they are a big component of enforcing a professional culture and should be part of the selection process to ensure new members have a realistic 
understanding of the situational/personal behaviours needed for successful value co-creation and customer-staff interactions.

While the focus of this study is on employee engagement, these systems and processes need to also facilitate customer interaction. For instance, situational factors require understanding customer needs that arise from customer-employee interaction, thus capturing customer-related factors such as the nature of communication, familiarity with guests, and type of interaction (physical versus virtual). These factors also include guest involvement, informal conversations, relationship building, customer status communication, and customer engagement. Customer engagement essentially reflects the customer's willingness and ability to engage, level of cooperation, preference for brand standards, and openness and familiarity. Customer involvement, attitude and behaviour appear reciprocal in nature and are influenced by how employees interact and the level of employee engagement. Customers' openness, willingness to share information and behaviour also influence the level of employee engagement in co-creation, given that both parties are involved. Above all, customers' needs and wants have a major influence on employee engagement. Meeting these needs should not be limited by the situational context; from a managerial perspective, the design of a hotel's engagement platforms should address as many situational factors as possible to minimise value deconstruction.

Although it is imperative that resources be allocated to facilitate service personalisation and thereby enhance employee engagement, situational requirements need to be considered in conjunction with the specificity of resources in terms of how they match customer specific needs. Technological interfaces may foster employee engagement in co-creation; such interfaces include state-of-the-art systems, communication tools, the hardware and software required to create effective interfaces and engagement platforms relevant to customeremployee interactions. Practitioners must consider these factors in the formulation of 
engagement platforms in hotel firms. Information management provides a basis for information flow in terms of availability, usage and storage, including updating, filtering and reinforcement. These systems should allow for effective interdepartmental communication and coordination to enhance situational engagement that accommodates variations in demand and individual needs in the situational context. Whilst situational factors tend to be transactional and related to the role of the customer in value co-creation, they can also be difficult to control and are largely extrinsic. This should be carefully considered by the management in managing the flow of information in hotels.

Firms would need to equally focus on personal factors of the employees in both selection and development to ensure sufficient customisation (see Table 2) and manage employee related influences. Many of the personal factors or variables identified in this study capture the employee's personal orientation towards co-creation. A key factor that management should consider is employees' propensity to seek, filter, process and share information, which reflects their capacity to process and manage customer related information. Employees' level of empathy in terms of anticipating customer needs and wants is key to greater engagement. Moreover, employee skills and work experience play a significant role in engagement, and include tenure, skills, training, exposure and problem-solving ability, which facilitate thinking 'outside the box'. Thus, employees' personality traits should be assessed and developed to enable them to engage in service transactions; these traits include service willingness, responsibility, empowered authority, proactiveness, demeanour, introspection, communication and inquisitiveness. Employee behaviour, attitude and motivation are equally important determinants of employee involvement and engagement, mindset, passion and enthusiasm, openness to ideas and change, and other characteristics such as ability to work with peers and customers. 
In a nutshell, this research significantly contributes to best practice relating to the role of service employees in co-creation of value. At the situational level, meeting customer specific requests while localising transactions to meet specific needs is essential to value co-creation. For instance, empowerment is an organisational factor that determines whether co-creation is materialised; however, the degree of operationalisation is dependent on key situational and personal factors that determine standards and procedural adaptation needs. This provides a basis for employees to ensure they have the tools to adapt to any situation. Authority, responsibility and professional engagement also play important roles in fostering a system in which employees are empowered. To ensure the effectiveness of brand standards, these standards must evolve to meet specific market and situational needs.

\section{Conclusions and suggestions for future research}

This research delved into the roles of factors and their effect on employee engagement in customer value co-creation. The primary objective was to identity key situational and personal factors/variables as part of a larger framework that can be used by researchers and practitioners alike to provide a suitable environment for employee engagement in co-creation based hospitality services. The research implications go beyond the hospitality domain by indicating how to conceptualise co-creation from an employee's perspective, which has not been addressed in the business literature. Accordingly, the findings provide a basis for incrementally determining how co-creative modalities can be integrated in evolving service transactions.

The categorisation of underlying situational and personal factors influencing employee engagement provides a basis for further exploration of hospitality service transactions that are co-creation oriented. Further research on employee engagement is warranted to establish the norms of co-creation based service exchanges. As many organisations today are using 
experiential value to connect with customers and co-creation to build brand based connections with customers, it is imperative for researchers to derive empirical models of employee engagement and value co-creation at all levels, situational and personal in particular. Future studies should develop measurement scales for all of the situational and personal factors using quantitative methodologies. Following this, the causal relationships between these factors and employee engagement in the co-creation of value needs testing and confirmation. The findings of this study provide a foundation for developing causal models that will explicate the cause and effect relationships between these situational and personal variables.

Apart from causal research, future research could explore these conceptual underpinnings to enhance our understanding of employee engagement in service co-creation. The importance of the current and future research relates to the need for hospitality firms to raise as much value as possible in the current competitive environment. Further, future research defining 1) the situational and personal factors that are likely to impact the construction or deconstruction of co-created value and 2) how firms can facilitate ways to enhance these reciprocal interrelationships throughout the customer journey would be beneficial. These research areas would broaden the lens for understanding how value can be co-created based on dynamic business context and experience based logic.

While this research provides a novel framework for future research, it is not without limitations. The three hotels involved in the study were well-established international brands with an upscale orientation. Although the hotels represent global level practices, the exploratory findings are not generalisable across the hotel population. Future research should implement appropriate methods to increase the generalisability of the findings. Quantitative studies should be the focus of future research to test the veracity of the findings. 


\section{References}

Assiouras, I., Skourtis, G., Giannopoulos, A., Buhalis, D., Koniordos, M., 2019. Value co-creation and customer citizenship behaviour. Annals of Tourism Research. 78, 1-11.

Bakker, A.B., Schaufeli, W.B., 2008. Positive organizational behavior: Engaged employees in flourishing organizations. Journal of Organizational Behavior. 29 (2), 147-154.

Binkhorst, E., Den Dekker, T., 2009. Agenda for co-creation tourism experience research. Journal of Hospitality Marketing \& Management. 18 (2-3), 311-327.

Buhalis, D., Foerste, M., 2015. SoCoMo marketing for travel and tourism: Empowering cocreation of value. Journal of Destination Marketing and Management. 4, 151-161.

Buonincontri, P., Morvillo, A., Okumus, F., van Niekerk, M., 2017. Managing the experience cocreation process in tourism destinations: Empirical findings from Naples. Tourism Management. 62, 264-277.

Chang, K.C., 2016. Effect of servicescape on customer behavioral intentions: Moderating roles of service climate and employee engagement. International Journal of Hospitality Management. $53,116-128$.

Chase, R.B., Dasu, S., 2014. Experience psychology - a proposed new subfield of service management. Journal of. Service Management. 25 (5), 574-577.

Chathoth, P.K., Mak, B., Jauhari, V., Manaktola, K., 2007. Employees' perceptions of organizational trust and service climate: a structural model combining their effects on employee satisfaction. Journal of Hospitality \& Tourism Research. 31 (3), 338-357.

Chathoth, P.K., Altinay, L., Harrington, R.J., Okumus, F., Chan, E., 2013. Co-production versus co-creation: A process based continuum in the hotel service context. International Journal of Hospitality Management. 32, 11-20.

Chathoth, P.K., Ungson, G.R., Altinay, L., Chan, E.S.W., Harrington, R., Okumus, F., 2014. Barriers affecting organisational adoption of higher order customer engagement in tourism service interactions. Tourism Management. 42 (1), 181-193.

Chathoth, P.K., Ungson, G.R., Harrington, R.J., Chan, E.S.W., 2016. Co-creation and higher order customer engagement in hospitality and tourism services A critical review. International Journal of Contemporary Hospitality Management. 28 (2), 222-245.

Chathoth, P.K., Chan, E., Harrington, R., Okumus, F., Song, Z., 2017. Co-creating custoemr experience: the role of employees in tourism and hospitality services. In: Presbensen, N.K., Chen, J., Uysal, M. (Eds.), Co-Creation in Tourist Experiences. Routlege.

Dai, Y. D., Zhuang, W. L., Huan, T. C., 2019. Engage or quit? The moderating role of 
abusive supervision between resilience, intention to leave and work engagement. Tourism Management. 70, 69-77.

Dong, B., Evans, K.R., Zou, S., 2008. The effects of customer participation in co-created service recovery. Journal of the Academy of Marketing Science. 36 (1), 123-137.

González-Mansilla, Ó., Berenguer-Contríb, G., Serra-Cantallops, A., 2019. The impact of value co-creation on hotel brand equity and customer satisfaction. Tourism Management. 75, 51-65.

Gordon, S., 2020. Organizational support versus supervisor support: The impact on hospitality managers' psychological contract and work engagement. International Journal of Hospitality Management. 87, 1-9.

Grönroos, C., 2008. Service logic revisited: who creates values? And who co-creates? European Business Review. 20 (4), 298-314.

Grönroos, C., 2012. Conceptualising value co-creation: A journey to the 1970s and back to the future. Journal of Marketing Management. 28 (13/14), 1520-1534.

Hansen, A.V., 2017. What stories unfold: Empirically grasping value co-creation. European Business Review. 29 (1), 2-14.

Harkison, T., 2018. The use of co-creation within the luxury accommodation experience myth or reality? International Journal of Hospitality Management. 71, 11-18.

Harrington, R.J., Fauser, S., Ottenbacher, M.C., 2017. QSR brand value strategies: Assessing perceived relative differences in marketing mix dimensions among brands, loyal customers and non-customers. International Journal of Contemporary Hospitality Management. 29 (1), 551-570.

Harrington, R.J., Hammond, R., Ottenbacher, M.C., Chathoth, P., Marlowe, B., 2019. From goods-service logic to a memory-dominant logic: Demand-side strategy research and application in hospitality. International Journal of Hospitality Management. 76, 252260.

Hwang, J., Seo, S., 2016. A critical review of research on customer experience management. International Journal of Contemporary Hospitality Management. 28 (10), 2218-2246. Johnston, N., Sharma, B., Spinks, W., 2013. Organisational climate, service climate and customer satisfaction: An investigation of their relationships in franchised hospitality enterprises. e-Journal of Social and Behavioural Research in Business. 4 (2), 34-51.

Kristensson, P., Matthing, J., Johansson, N., 2008. Key strategies for the successful Involvement of customers in the co-creation of new technology-based services. Journal of Service Management. 19 (4), 475-491.

Krueger, R.A., Casey, M.A., 2000. Focus groups: A practical guide for applied researchers 
(3rd ed.). Sage, Thousand Oaks, CA.

Lashley, C., 2017. The Routledge handbook of hospitality studies. Routledge, New York, N.Y.

Lemon, K.N., Verhoef, P.C., 2016. Understanding customer experience throughout the customer journey. Journal of Marketing. 80, 69-96.

Lusch, R.F., Vargo, S.L., 2006. Service-Dominant Logic as a Foundation for a General Theory, in R.F. Lusch and S.L. Vargo (eds), The Service-Dominant Logic of Marketing: Dialog, Debate, and Directions, pp. 406-420. Armonk, NY: ME Sharpe.

Ma, S., Gu, H., Wang, Y., Hampson, D.P., 2017. Opportunities and challenges of value cocreation: The role of customer involvement in hotel service development. International Journal of Contemporary Hospitality Management. 29 (12), 3023-3043.

Miles, M.B., Huberman, A.M., 1994. Qualitative Data Analysis. Sage, Thousand Oaks, CA.

Mullins, L.J., 2007. Management and organizational behaviour (8th ed.). Pearson Education, Upper Saddle River, NJ.

Paek, S., Schuckert, M., Kim, T. T., Lee, G., 2015. Why is hospitality employees' Psychological capital important? The effects of psychological capital on work engagement and employee morale. International Journal of Hospitality Management. 50, 9-26.

Payne, A.F., Storbacka, K., Frow, P., 2008. Managing the co-creation of value. Journal of the Academy of Marketing Science. 36 (1), 83-96.

Pine, B., Gilmore, J. H., 1998. Welcome to the experience economy. Harvard Business Review. $76(4), 97-105$.

Prahalad, C.K., Ramaswamy, V., 2004a. The future of competition: Co-creating unique value with customers. Harvard Business School Press, Boston, MA.

Prahalad, C.K., Ramaswamy, V., 2004b. Co-creation experiences: The next practice in value creation. Journal of Interactive Marketing. 18 (3), 5-14.

Prebensen, N.K., Xie, J., 2017. Efficacy of co-creation and mastering perceived value and satisfaction in tourists' consumption. Tourism Management. 60, 166-176.

Rabiee, F., 2004. Focus-group interview and data analysis. Proceedings of the Nutrition Society. $63(4), 655-660$.

Ramaswamy, V., Guillart, F., 2010. Building the co-creative enterprise: give all your stakeholders a bigger say, and they'll lead you to better insights, revenues, and profits. Harvard Business Review. 88 (10), 100-109. 
Ramaswamy, V., Ozcan, K., 2018. What is co-creation? An interactional creation framework and its implications for value creation. Journal of Business Research. 84, 196-205.

Salanova, M., Agut, S., Piero, J.M., 2005. Linking organizational resources and work engagement to employee performance and customer loyalty: The mediation of service climate. Journal of Applied Psychology. 90, 1217-1227.

Shaw, G., Bailey, A., William, A., 2011. Aspects of service-dominant logic and its Implications for tourism management: Examples from the hotel industry. Tourism Management. 32 (2), 207-214.

Smith, J.B., Colgate, M., 2007. Customer value creation: A practical framework. Journal of Marketing Theory and Practice. 15 (1), 7-23.

Tsaur, S. H., Hsu, F. S., Lin, H., 2019. Workplace fun and work engagement in tourism and hospitality: The role of psychological capital. International Journal of Hospitality Management. 81, 131-140.

Vargo, S.L., Lusch, R.F., 2004. Evolving to a new dominant logic for marketing. Journal of Marketing. 68 (1), 1-17.

Voorhees, C. M., Fombelle, P. W., Gregoire, Y., Bone, S., Gustafsson, A., Sousa, R., Walkowiak, T., 2017. Service encounters, experiences and the customer journey: Defining the field and a call to expand our lens. Journal of Business Research. 79, 269-280.

White, T.R., Hede, A., Rentschler, R., 2009. Lessons from arts experiences for service-dominant logic. Marketing Intelligence \& Planning. 27 (6), 775-788.

Yachin, J.M., 2018. The 'customer journey': Learning from customers in tourism experience encounters. Tourism Management Perspectives. 28, 201-210.

Yi, Y., Gong, T., 2013. Customer value co-creation behavior: Scale development and validation. Journal of Business Research. 66 (9), 1279-1284.

Yin, R.K., 2009. Case Study Research: Design and Methods (4the ed.). Sage, Thousand Oaks, CA. 


\section{Appendix A}

\section{Primary Items Included in the Open-ended Interview Protocol}

- Does your hotel adjust products and services to suit the individual needs/wants of the guest? If so, how?

- What role does the employee play in creating guest experiences? What resources are available to the employee to create such experiences?

- To what extent are your employees able to modify the goods or services delivered (in relation to standard operating procedures)? Please provide some examples from operations.

- Do you see the guests' and employees' roles in creating experiences as related to their past, present and future interactions? How so?

- How are employees managed/trained to deal with managing customer experiences? Is there system-wide training?

- Do you assess employees' experiences in terms of service outcomes? How are employees evaluated in terms of their success in creating guest experiences?

- How do you treat the information provided by your guests at various stages of their interactions with you? Please provide examples from operations.

- What do you do if the information provided by the guest is not adequate? How do employees go about collecting more information? Please provide examples.

- From the point of view of your hotel and guests, what do you see as barriers or impediments to guests and employees being involved in the creation of experience? 
Table 1

Focus Group Participants' Responses to Closed-ended Questions

\begin{tabular}{|c|c|c|c|c|c|c|}
\hline \multirow{5}{*}{$\begin{array}{c}\text { Summary } \\
\text { of } \\
\text { Responses }\end{array}$} & & Very High & High & Average & Low & Very Low \\
\hline & Q1A & 8 & 25 & 9 & 0 & 0 \\
\hline & Q1B & 4 & 21 & 17 & 0 & 0 \\
\hline & Q1C & 11 & 22 & 9 & 0 & 0 \\
\hline & Q1D & 9 & 22 & 11 & 0 & 0 \\
\hline & & & & & & \\
\hline
\end{tabular}


Table 2

Situational and Personal Factors Influencing Employee Engagement in Value Cocreation

\begin{tabular}{|c|c|}
\hline Situational factors & Key Variables \\
\hline $\begin{array}{l}\text { Understanding customer } \\
\text { needs }\end{array}$ & $\begin{array}{ll}\text { - } & \text { Nature of transaction } \\
\text { - } & \text { Underlying factors influencing needs } \\
\text { - } & \text { Customer motivation }\end{array}$ \\
\hline $\begin{array}{l}\text { Customer-employee } \\
\text { interaction }\end{array}$ & $\begin{array}{ll}\text { - } & \text { Nature of communication } \\
\text { - } & \text { Familiarity with guests } \\
\text { - } & \text { Type of interaction - personal versus virtual } \\
\text { - } & \text { Guest involvement } \\
\text { - } & \text { Informal conversations } \\
\text { - } & \text { Employee satisfaction } \\
\text { - } & \text { Relationship building }\end{array}$ \\
\hline Customer status & $\begin{array}{ll}\text { - } & \text { VVIP/VIP } \\
\text { - } & \text { Loyalty/frequency of use } \\
\text { - } & \text { Purpose of visit }\end{array}$ \\
\hline Customer engagement & $\begin{array}{ll}\text { - } & \text { Willingness and ability to engage } \\
\text { - } & \text { Cooperation } \\
\text { - } & \text { Degree of institutionalisation and standardisation } \\
\text { - } & \text { Openness } \\
\text { - } & \text { Familiarity }\end{array}$ \\
\hline $\begin{array}{l}\text { Customer attitude and } \\
\text { behaviour }\end{array}$ & $\begin{array}{ll}\text { - } & \text { Customer background and communication skills } \\
\text { - } & \text { Customer openness } \\
\text { - } & \text { Familiarity } \\
\text { - } & \text { Duration of interaction } \\
\text { - } & \text { Cost and benefit }\end{array}$ \\
\hline Personal factors & Key Variables \\
\hline $\begin{array}{l}\text { Employee's propensity to } \\
\text { process information }\end{array}$ & $\begin{array}{ll}\text { - } & \text { Information seeking behaviour } \\
\text { - } & \text { Affinity for information processing } \\
\text { - } & \text { Information processing ability and skills } \\
\text { - } & \text { Level of motivation to manage information flow }\end{array}$ \\
\hline Employees' level of empathy & - $\quad$ Anticipating customer needs and wants \\
\hline
\end{tabular}




\begin{tabular}{|c|c|}
\hline $\begin{array}{l}\text { Employee skills and work } \\
\text { experience }\end{array}$ & $\begin{array}{ll}\text { - } & \text { Tenure } \\
\text { - } & \text { Work experience } \\
\text { - } & \text { Skills } \\
\text { - } & \text { Training } \\
\text { - } & \text { Exposure } \\
\text { - } & \text { Familiarity with guests } \\
\text { - } & \text { Thinking 'outside the box' } \\
\text { - } & \text { Managing service outcomes } \\
\text { - } & \text { Problem solving ability }\end{array}$ \\
\hline $\begin{array}{l}\text { Employee behaviour, attitude } \\
\text { and motivation }\end{array}$ & $\begin{array}{ll}\text { - } & \text { Level of involvement and engagement } \\
\text { - } & \text { Positive mindset } \\
\text { - } & \text { Passion and enthusiasm } \\
\text { - } & \text { Opiving and caring attitude } \\
\text { - } & \text { Connecting with customers and peers } \\
\text { - } & \text { Flexibility } \\
\text { - } & \text { Creating 'wow' moments for customers } \\
\text { - } & \text { Recognition }\end{array}$ \\
\hline Employee personality traits & $\begin{array}{ll}\text { - } & \text { Willingness to engage } \\
\text { - } & \text { Ownership of service situation } \\
\text { - } & \text { Responsibility } \\
\text { - } & \text { Managing authority } \\
\text { - } & \text { Managing stress and work-life balance } \\
\text { - } & \text { Emotionality } \\
\text { - } & \text { Demeanour } \\
\text { - } & \text { Proactiveness } \\
\text { - } & \text { Introspection } \\
\text { - } & \text { Responsiveness } \\
- & \text { Inquisitiveness } \\
\text { - } & \text { Interpersonal communication }\end{array}$ \\
\hline
\end{tabular}


Figure 1

\section{Situational and Personal Factors Influencing Value Co-creation}

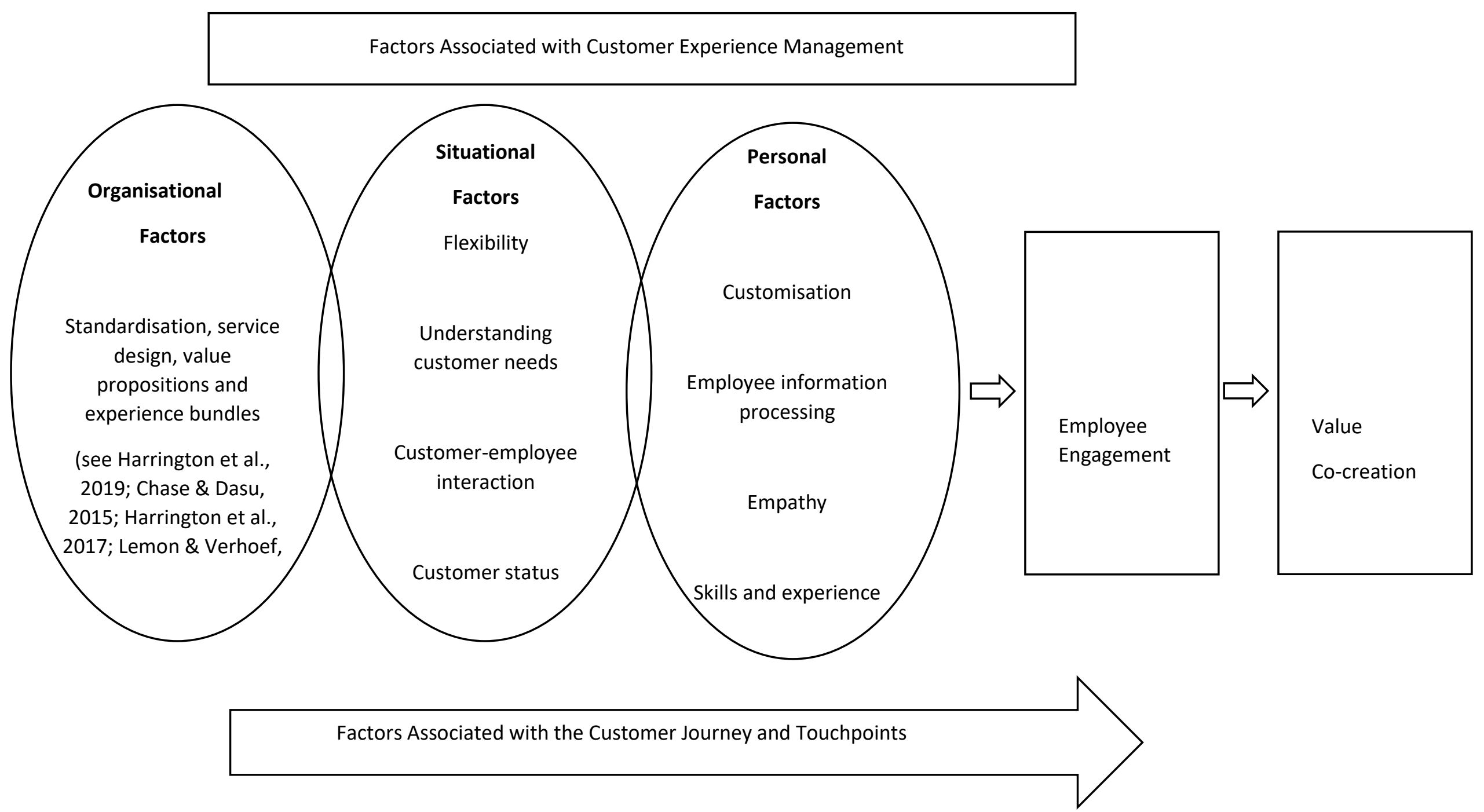

